\title{
GAMBARAN STRESS DAN DAMPAKNYA PADA MAHASISWA
}

\section{DESCRIPTION OF STRESS AND ITS IMPACT ON STUDENTS}

\author{
Sugiarti A. Musabiq ${ }^{1}$, Isqi Karimah ${ }^{2}$ \\ ${ }^{12}$ University of Indonesia, Kampus Baru UI, Depok, 16424, Indonesia \\ sugiartipsi@gmail.com
}

\begin{abstract}
Abstrak
Penelitian ini dilakukan untuk mengetahui gambaran umum stress dan dampaknya pada mahasiswa yang dilihat dari kejadian sehari-hari. Sampel dari penelitian ini adalah mahasiswa Fakultas Psikologi Universitas Indonesia. Sebanyak 67 mahasiswa psikologi berpartisipasi dengan cara mengisi survey berbentuk pertanyaan terbuka tentang kejadian-kejadian yang menimbulkan stress serta dampak yang dirasakan dalam rentang waktu lima hari terakhir. Hasil penelitian menunjukkan bahwa sebagian besar mahasiswa memiliki lebih dari satu jenis stressor dan merasakan dampak dari stress di lebih dari satu aspek. Jenis stressor terbanyak yang dimiliki mahasiswa berasal dari intrapersonal (29.3\%), yaitu berupa kondisi keuangan (23\%) dan tanggung jawab di organisasi kampus (20\%). Selain itu, hasil penelitian menunjukkan bahwa stress memiliki dampak terbesar terhadap aspek fisik (32\%). Hal yang sangat sering dirasakan adalah kelelahan dan lemas $(21.1 \%)$.
\end{abstract}

Kata Kunci: Dampak Stress, Distress, Mahasiswa, Stressor

\begin{abstract}
Abstrack
This research was conducted to get the general picture of stress and its impact on students seen from daily events. The sample from this study was students of the Faculty of Psychology, University of Indonesia. A total of 67 psychology students participated by filling out surveys in the form of open questions about events that caused stress and the impact felt in the past five days. The results of the study show that most students have more than one type of stressor and feel the effects of stress in more than one aspect. The most types of stressors students have come from intrapersonal (29.3\%), which are in the form of financial conditions (23\%) and responsibilities in campus organizations (20\%). In addition, the results of the study show that stress has the greatest impact on physical aspects (32\%). The thing that is very often felt is fatigue and weakness $(21.1 \%)$.
\end{abstract}

Keywords: Stress, Impact of Stress, College Students, Stressors

\section{PENDAHULUAN}

Stress merupakan hal yang sering ditemui dan sulit dihindari dalam kehidupan sehari-hari, bahkan Seyle (1976, dalam Ridner, 2004) menyebutkan bahwa tanpa adanya stress, maka tidak akan ada kehidupan. Stress adalah respon non-spesifik dari tubuh terhadap segala tuntutan, baik respon positif maupun respon negatif (Seyle, 1976 dalam Ridner, 2004). Pengertian lain menyebutkan bahwa stress merupakan respon individu terhadap adanya stressor (Mulhall, 1996, dalam Barnes \& Montefusco, 2011). Aneshenhel (1992, dalam Barnes \& Montefusco, 2011) menjelaskan bahwa stressor merupakan stimulus, baik eksternal, maupun internal, yang berpotensi menjadi penyebab terjadinya stress.

Stressor terbagi ke dalam beberapa kategori, yaitu life events, chronic stressor, dan daily hassles (Barnes \& Montefusco, 2011). Life events adalah jenis stressor yang berasal dari kejadian 
yang akut, diskrit, dan dapat diobservasi yang mengharuskan adanya penyesuaian diri kembali dalam jangka waktu yang singkat, misalnya setelah melahirkan atau bercerai (Wheaton, 1999, dalam Barnes \& Montefusco, 2011). Chronic stressor adalah jenis stressor yang berasal dari kejadian, masalah, atau konflik yang bertahan cukup lama yang mengakibatkan butuhnya penyesuaian diri dalam waktu yang cukup lama pula, misalnya kecacatan atau kemiskinan (Wheaton, 1999, dalam Barnes \& Montefusco, 2011). Daily hassles adalah jenis stressor yang membutuhkan sedikit penyesuaian sepanjang hari yang bersangkutan, misalnya kemacetan (Thoits, 1995, dalam Barnes \& Montefusco, 2011).

Dalam konteks mahasiswa, terdapat empat sumber stress pada mahasiswa yaitu interpresonal, intrapersonal, akademik, dan lingkungan (Ross, Niebling, \& Heckert, 2008). Interpersonal adalah stressor yang dihasilkan dari hubungan dengan orang lain, misalnya konflik dengan teman, orang tua, atau pacar. Intrapersonal adalah stressor yang berasal dari dalam diri individu itu sendiri, misalnya kesulitan keuangan, perubahan kebiasaan makan atau tidur, dan kesehatan menurun. Akademik adalah stressor yang berhubungan dengan aktivitas perkuliahan dan masalah yang mengikutinya, misalnya nilai ujian yang jelek, tugas yang banyak, dan materi pelajaran yang sulit. Lingkungan adalah stressor yang berasal dari lingkungan sekitar, selain akademik, misalnya kurangnya waktu liburan, macet, dan lingkungan tempat tinggal yang tidak nyaman (Ross, Niebling, \& Heckert, 2008). Pada penelitian ini, peneliti fokus pada sumber stress yang berasal dari daily hassles pada mahasiswa.

Berdasarkan respon yang dihasilkan, stress terbagi menjadi dua yaitu eustress dan distress. Eustress adalah respon positif terhadap stress sedangkan distress adalah respon negatif terhadap stress (Seyle, 1976 dalam Ridner, 2004). Berdasarkan hukum Yerkes- Dodson, dalam jumlah tertentu stress menghasilkan kekuatan positif yang mampu meningkatkan produktivitas individu dan membantu individu untuk berkembang, setelah mencapai titik optimal, stress bersifat destruktif dan menimbulkan efek negatif bagi individu (dalam Hanoch \& Vitouch, 2004).

Banyak dampak negatif yang dihasilkan dari distress. Winkleman (1994, dalam Misra \& Castillo, 2004) menyebutkan bahwa distress secara fisik akan mengakibatkan kurangnya energi dari tubuh secara persisten, kurangnya nafsu makan, sakit kepala dan lambung. Penelitian lain menyebutkan bahwa tingginya tingkat distress, khususnya pada mahasiswa, berpengaruh terhadap kecemasan dan depresi, keinginan untuk bunuh diri, pola hidup yang buruk, gangguan pola tidur, sakit kepala, dan perasaan tidak berdaya (Oman, Shapiro, Thoresen, \& Plante, 2008). Bressert (2016) juga menglasifikasikan dampak stress ke dalam empat aspek yaitu fisik, kognitif, emosi, dan perilaku. Menurut Bressert (2016), beberapa tanda bahwa stress telah berdampak pada fisik diantaranya adalah adanya gangguan tidur, peningkatan detak jantung, ketegangan otot, pusing dan demam, kelelahan, dan kekurangan energi. Adanya dampak pada aspek kognitif ditandai dengan adanya kebingungan, sering lupa, kekhawatiran, dan kepanikan. Pada aspek emosi, dampak dari stress diantaranya adalah mudah sensitif dan mudah marah, frustrasi, dan merasa tidak berdaya. 
Pada aspek perilaku, stress berdampak pada hilangnya keinginan untuk bersosialisasi, kecenderungan untuk ingin menyendiri, keinginan untuk menghindari orang lain, dan timbulnya rasa malas (Bressert, 2016). Melihat adanya pengaruh negatif dari distress ini, khususnya pada mahasiswa, membuat peneliti tertarik untuk mengetahui gambaran stress dan dampaknya pada mahasiswa.

Secara umum, di Indonesia, mahasiswa rata-rata berada di rentang usia 18- 24 tahun. Menurut tahapan perkembangan, mahasiswa berada pada tahapan perkembangan dewasa muda (santrock, 2008). Pada tahapan perkembangan ini, mahasiswa berusaha mengeksplorasi diri untuk menemukan identitas diri yang sesungguhnya, berusaha untuk bergaul, membina hubungan dan mengemban tanggung jawab sosial (Hurlock, 1980). Ditambah lagi, terdapat beban akademik serta kegiatan kampus lainnya sebagai salah satu tanggung jawab sebagai "mahasiswa" yang harus dipenuhi. Dalam memenuhi tugas perkembangan tersebut, tak jarang ditemukan masalah-masalah yang memicu timbunya stress. Dampak yang dihasilkan dari stress tersebut pun beragam mulai dari hal yang ringan, seperti sakit kepala dan tidak nafsu makan, hingga hal yang paling fatal, yaitu bunuh diri. Dengan kata lain, stress berubah menjadi distress. Sebagai contoh, pada tahun 2016 ditemukan mahasiswa yang bunuh diri dengan cara gantung diri di kamar dengan tidak diketahui penyebab pastinya (Hamdi, 2016). Peristiwa serupa pun terjadi pada tahun 2012, seorang mahasiswa ditemukan tewas bunuh diri dengan cara terjun bebas dari lantai 18 di sebuah apartemen (Prihananto, 2012).

Sebelum sampai pada puncak respon dari stress, yaitu bunuh diri, peneliti merasa perlu untuk meneliti hal-hal apa saja yang menjadi sumber stress mahasiswa dan dan dampak yang dihasilkan dari stress tersebut. Pada penelitian ini, peneliti akan melihat gambaran sumber stress dan dampaknya dari beberapa aspek pada populasi mahasiswa S1 di Kota Depok. Hasil penelitian ini diharapkan mampu dijadikan rujukan dalam pembuatan program intervensi yang tepat dalam mengurangi dan mengatasi stress pada mahasiswa. Berdasarkan latar belakang tersebut, maka masalah yang akan dijawab dalam penelitian ini yaitu "Bagaimana gambaran stress dan dampaknya pada mahasiswa?"

\section{METODE}

Penelitian ini merupakan penelitian kuantitatif dan deskriptif. Karateristik partisipan dalam penelitian ini adalah mahasiswa aktif semester satu hingga delapan di Wilayah Depok, Provinsi Jawa Barat. Kota Depok dipilih karena merupakan salah satu kota pendidikan. Diperkirakan terdapat seratus ribu mahasiswa yang menuntut ilmu di Kota Depok, baik dari dalam kota maupun luar kota (Esti, 2015). Metode pengambilan sample yang dilakukan adalah non-probability sampling. Peneliti melakukan penelitian berdasarkan kesediaan dan keinginan dari partisipan. Universitas Indonesia dipilih sebagai sample karena Universitas Indonesia merupakan salah satu universitas terbaik negeri yang berada di Kota Depok dengan standar pendidikan tinggi. Selain itu, 
Universitas Indonesia memiliki mahasiswa yang berasal dari berbagai daerah di Indonesia yang terkenal aktif dan dinamis dengan berbagai kegiatan kepanitiaan dan organisasi. Dengan kondisi tersebut kemungkinan adanya banyak stressor yang ditemui oleh mahasiswa dalam kehidupan sehari-hari dan kemungkinan mahasiswa untuk mengalami distress cukup tinggi.

Penelitian dilakukan pada 67 mahasiswa Fakultas Psikologi Universitas Indonesia. Peneliti melakukan survey dengan memberikan pertanyaan terbuka kepada mahasiswa tentang lima kejadian sehari-hari dalam lima hari terakhir yang menimbulkan stress serta dampak yang dirasakan. Mahasiswa diminta untuk menuliskannya di atas kertas dan diminta untuk menuliskan umur dan jenis kelamin, lalu dikumpulkan. Data yang telah terkumpul kemudian dikelompokkan berdasarkan teori yang digunakan, lalu dihitung secara kuantitatif dengan teknik analisis statistik deskriptif.

\section{HASIL DAN PEMBAHASAN}

Data yang diperoleh peneliti sebanyak 64 partisipan. Di bawah ini merupakan gambaran distribusi partisipan berdasarkan data yang peneliti sebutkan dalam instruksi penelitian.

\section{Gambaran Umum Partisipan}

Gambaran umum mengenai partisipan dalam penelitian ini dapat dilihat pada tabel 1 berikut:

Tabel 1. Gambaran Umum Partisipan ( $N=64)$

\begin{tabular}{lcc}
\hline Karakteristik & F & P \\
\hline Usia & & \\
18 tahun & 17 & $26.6 \%$ \\
19 tahun & 35 & $54.7 \%$ \\
20 tahun & 10 & $15.6 \%$ \\
21 tahun & 1 & $1.6 \%$ \\
22 tahun & 1 & $1.6 \%$ \\
Jenis Kelamin & & \\
Laki-Laki & 2 & $3.1 \%$ \\
Perempuan & 62 & $96.9 \%$ \\
\hline
\end{tabular}

Sebagian besar partisipan berusia 19 tahun dengan jumlah sebesar 54.7\% dari total partisipan. Berdasarkan jenis kelamin, diketahui bahwa sebagian besar partisipan berjenis kelamin perempuan dengan jumlah sebesar $96.9 \%$ dari total partisipan.

\section{Jenis Stressor}

Jenis stressor yang dialami oleh partisipan dalam penelitian ini dapat dilihat pada tabel 1 berikut: 
Tabel 2. Gambaran Umum Jenis Stressor

\begin{tabular}{ccc} 
Jenis Stressor & F & P \\
\hline Interpersonal & 54 & $18.6 \%$ \\
Intrapersonal & 85 & $29.3 \%$ \\
Akademik & 78 & $26.9 \%$ \\
Lingkungan & 73 & $25.2 \%$ \\
\hline
\end{tabular}

Sebagian besar stress pada mahasiswa bersumber dari masalah intrapersonal dengan nilai sebesar 29.3\%. Mahasiswa yang mengalami stress pada sumber ini sebagian besar mengalami masalah dengan keuangan (23\%) dan adanya tanggung jawab di organisasi kampus (20\%). Dalam masalah keuangan, stress muncul karena banyaknya pengeluaran, tidak adanya uang untuk pulang ke rumah, membayar uang kuliah, atau untuk membeli buku, serta belum turunnya uang beasiswa sedangkan uang bulanan semakin menipis. Pada aktivitas organisasi, stress muncul karena banyaknya program dan tanggung jawab di organisasi yang harus diselesaikan. Hal lain yang memicu stress pada sumber ini yaitu sulitnya mengatur waktu (10\%), kesehatan yang memburuk (6\%), gambaran tubuh yang tidak ideal (3.6\%), adanya keluarga yang sakit (3.6\%), dan pola hidup yang kurang baik (2.4\%).

Jenis stressor yang menjadi sumber stress kedua bagi mahasiswa berasal dari kegiatan akademik dengan nilai sebesar 29.6\%. Stress pada akademik sebagian besar disebabkan oleh banyaknya tugas yang sudah ada bahkan di minggu awal kuliah (48.7\%). Hal lain yang memicu stress pada sumber ini yaitu sulitnya memahami mata kuliah $(9.2 \%)$, rencana studi yang bermasalah (7.9\%), jadwal kuliah yang padat (3.9\%), dan nilai yang jelek (3.9\%).

Jenis stressor yang menjadi sumber stress ketiga bagi mahasiswa berasal dari lingkungan dengan nilai sebesar $25.2 \%$. Stress yang berasal dari lingkungan sebagian besar disebabkan oleh masalah di organisasi yang sedang diikuti $(42.5 \%)$. Dalam organisasi, stress muncul karena agenda organisasi yang padat dan menyita waktu serta tugas-tugas organisasi yang sudah dibatas waktu. Hal lain yang menjadi sumber stress dari lingkungan yaitu adalah lingkungan tempat tinggal yang tidak nyaman (15.1\%), misalnya kamar berantakan, banyak baju kotor, teman pindah ke luar kota, dan terganggu dengan tetangga; kemacetan dan transportasi (12.3\%), misalnya kereta datang terlambat, tarif tol naik dan jalan macet; tidak adanya waktu liburan (9.6\%), Gadget yang rusak (9.6\%); serta cuaca (2.7\%), misalnya hujan deras dan panas.

Jenis stressor yang menjadi sumber stress terakhir pada mahasiswa berasal dari masalah interpersonal (29.3\%). Sebagian besar masalah interpersonal berasal dari konflik dengan kekasih (27.8\%). Hal lain yang memicu stress pada sumber ini yaitu konflik dengan teman (14.8\%), berpisah dengan pacar, teman, dan keluarga (14.8\%), konflik dengan keluarga (13\%), serta salah paham (1.9\%). 
Gambaran umum jumlah jenis stressor partisipan dalam penelitian ini dapat dilihat pada tabel 1 berikut:

Tabel 3. Gambaran Umum Jumlah Jenis Stressor

\begin{tabular}{ccc}
$\begin{array}{c}\text { Jumlah } \\
\text { Stressor }\end{array}$ & F & P \\
\hline Satu & 2 & $3.1 \%$ \\
Dua & 19 & $29.7 \%$ \\
Tiga & 32 & $50 \%$ \\
Empat & 11 & $17.2 \%$ \\
\hline
\end{tabular}

Dalam jangka waktu kurang dari satu minggu, sebanyak 50\% mahasiswa mengalami kejadian pemicu stress yang berasal dari tiga jenis stressor. Misalnya interpersonal, akademik, dan lingkungan. Hanya 3.1\% mahasiswa yang memiliki kejadian pemicu stress yang berasal dari satu jenis stressor. Misalnya, akademik saja.

\section{Dampak Stress}

Gambaran umum mengenai dampak stress yang dialami oleh partisipan dalam penelitian ini dapat dilihat pada tabel 1 berikut:

Grafik 1. Gambaran Umum Dampak Stress

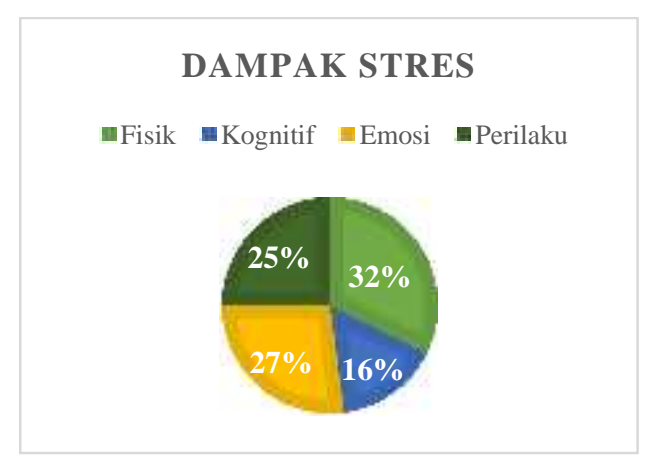

Berdasarkan grafik tersebut dapat disimpulkan bahwa stress memiliki dampak terbesar terhadap kondisi fisik mahasiswa (32\%). Dampak terbesar yang paling dirasakan oleh mahasiswa adalah merasa kelelahan dan lemas $(21.1 \%)$. Hal lain yang dirasakan adalah sakit kepala, pusing, atau migrain (20.3\%); gangguan makan (8.9\%); nyeri, badan pegal dan tegang otot (8.9\%); mudah sakit atau kesehatan tubuh menurun (8.1\%), gangguan tidur (8.1\%), dan gangguan pencernaan atau sakit perut $(5.7 \%)$.

Dampak kedua yang ditimbulkan dari stress yaitu dampak emosi dengan nilai sebesar (27\%). Sebagian besar mahasiswa merasakan mudah marah ketika merasa stress (30.6\%). Hal lain yang dirasakan yaitu lebih mudah menangis $(13.2 \%)$, suasana hati buruk $(14,2 \%)$, lebih sensitif 
$(11,2 \%)$, mudah tersinggung $(4,1 \%)$, tertekan $(4.1 \%)$; serta sedih, risih, khawatir, murung, dan hampir frustasi $(1 \%)$.

Dampak ketiga dari stress yaitu dampak perilaku dengan nilai sebesar 25\%. Sebagian besar mahasiswa merasa bahwa hubungan dengan teman, keluarga, serta orang lain memburuk (23\%). Hal lain yang dirasakan yaitu adanya kecenderungan untuk menyendiri dan malas berbicara, bertemu, atau berinteraksi dengan orang lain (20\%); lebih pendiam (8.5\%); malas mengerjakan tugas atau hal lain $(6.1 \%)$, tidak peduli dengan orang lain dan lingkungan sekitar, serta menjadi pemalu, tidak percaya diri, berteriak tanpa alasan, dan kurang mengerjakan tugas dengan maksimal $(1.2 \%)$.

Dampak terkecil yang dihasilkan dari stress adalah dampak kognitif dengan nilai sebesar $16 \%$. Sebagian besar mahasiswa yang terkena dampak kognitif dari stress merasakan sulit untuk konsentrasi atau fokus, baik saat mengerjakan tugas maupun saat berbicara dengan orang lain (21.7\%). Hal lain yang dirasakan yaitu pikiran tidak tenang (15.25\%), bingung (15.25\%), panik $(10,8 \%)$, sering termenung (13\%), serta berpikiran negatif, mudah lupa, dan kurang teliti $(2.1 \%)$.

Gambaran jumlah dampak yang ditimbulkan oleh stress pada partisipan dalam penelitian ini dapat dilihat pada tabel 1 berikut:

Grafik 2. Jumlah Dampak yang Ditimbulkan

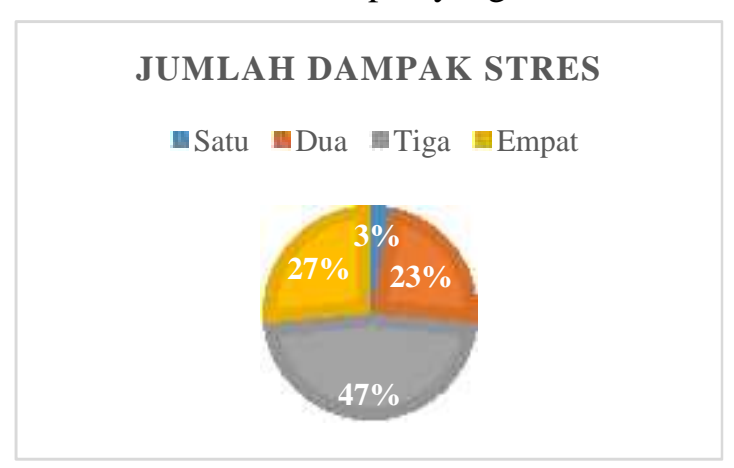

Tidak semua aspek terkena dampak dari stress. Sebagian besar mahasiswa, yaitu sebanyak $47 \%$, terkena dampak stress dari tiga aspek sekaligus (misalnya fisik, kognitif, dan emosi). Hanya sedikit mahasiswa, yaitu sebanyak 3\%, yang terkena dampak stress di satu aspek saja (misalnya fisik/kognitif/emosi/perilaku).

\section{DISKUSI}

Berdasarkan hasil penelitian ini, dapat diketahui bahwa sebagian besar mahasiswa memiliki lebih dari satu jenis stressor. Hal ini dapat diinterpretasikan bahwa dalam rentang waktu tertentu, mahasiswa mengalami kejadian pemicu stress yang bersumber dari akademik, interpersonal, intrapersonal, atau lingkungan secara bersamaan. Secara berurutan, jenis stressor yang paling sering dialami dari tinggi ke rendah adalah intrapersonal, akademik, lingkungan, dan interpersonal. 
Jumlah stressor terbanyak berasal dari intrapersonal, seperti keadaan keuangan dan manajemen waktu. Hasil penelitian ini juga menunjukkan bahwa stress berdampak terhadap lebih dari satu aspek individu, yaitu fisik, kognitif, emosi, atau perilaku. Berdasarkan dampak yang paling banyak dihasilkan, secara berurutan, stress berdampak pada aspek fisik, emosi, perilaku, dan kognitif. Stress memiliki dampak terbesar terhadap keadaan fisik individu. Hal yang sangat sering dirasakan adalah kelelahan dan lemas.

Terdapat beberapa kekurangan dalam penelitian ini yang dapat diperbaiki dalam penelitian berikutnya. Pertama, Penelitian ini hanya dilakukan pada salah satu fakultas di salah satu universitas di Kota Depok. Untuk mendapatkan hasil yang lebih umum, penelitian selanjutnya disarankan untuk mengambil sampel yang lebih banyak dengan ruang lingkup universitas yang lebih luas, baik negeri maupun swasta, di Kota Depok. Selain itu, persebaran partisipan antara lakilaki dan perempuan tidak merata sehingga hasil penelitian tidak dapat dibandingkan antara lakilaki dan perempuan. Berdasarkan hasil penelitian, ditemukan bahwa terdapat perbedaan pada aspek pikiran dan tubuh (mind-body difference) antara laki-laki dan perempuan dalam menghadapi distress dan stress (Juster, 2009). Oleh sebab itu, untuk lebih memperkaya hasil penelitian, pada penelitian selanjutnya disarankan untuk menyeimbangkan jumlah partisipan laki-laki dan perempuan.

Kedua, dalam mengukur hal-hal yang menyebabkan stress dan dampaknya, sebaiknya diberikan survey dalam bentuk pertanyaan tertutup dengan kategori-kategori stressor dan dampaknya yang telah disediakan. Hal ini dilakukan untuk menyamakan persepsi tentang stressor dan pengelompokan dampaknya serta meminimalisir variasi jawaban yang sulit dikelompokkan. Penting untuk diketahui cara mahasiswa dalam menghadapi stress. Oleh sebab itu penelitian selanjutnya sebaiknya mencari tahu tentang gambaran umum cara mahasiswa dalam menghadapi stress serta efektifitas dari cara penanganan tertentu (coping stress) terhadap tingkat stress pada mahasiswa.

\section{KESIMPULAN}

Berdasarkan penelitian tersebut dapat disimpulkan bahwa sebagian besar mahasiswa memiliki lebih dari satu jenis stressor dengan stressor terbesar berasal dari aspek interpersonal. Sebagian besar mahasiswa memilikil lebih dari tiga jenis stressor dalam seminggu. Selain itu, ditemukan juga bahwa stress berdampak terhadap lebih dari satu aspek kehidupan mahasiswa dengan dampak terbesar terdapat pada aspek fisik. Penelitian ini cukup memberikan gambaran mengenai gambaran stress dan dampaknya pada mahasiswa. Gambaran tersebut dapat dijadikan sumber bagi pihak universitas untuk melaksanakan intervensi sebagai sarana pencegahan atau penanganan dampak dari stress. 


\section{DAFTAR PUSTAKA}

Barnes, A.P., \& Montefusco, J.E. (2011). Role of stress in psychological disorders. New York: Nova Science Publisher, Inc.

Bressert, S. (2016). The impact of stress. Psych Central. Diunduh dari https://psychcentral.com/lib/the-impact-of-stress.

Esti, F. (2015). Properti kota depok makin menggairahkan. Property $n$ Bank. Diunduh dari http://www.propertynbank.com/properti-kota-depok-makin-menggairahkan/.

Hamdi, I. (2016, Juni 2). Mahasiswa UI bunuh diri: bukan soal nilai, ini yang terjadi. Tempo. Diunduh dari https://m.tempo.co/.

Hanoch, Y., \& Vitouch, O. (2004). When less is more: information, emotional arousal and the ecological reframing of the Yerkes- Dodson Law. Theory \& Psychology, 14(4), 427- 452.

Hurlock, E.B. (1980). Psikologi perkembangan suatu pendekatan sepanjang rentang kehidupan (5th ed.). Penerjemah: Istiwidayanti. Jakarta: Erlangga.

Juster, R.P. (2009, Maret). Mind-body differences in distress and stress reactivity among the sexes. Mamoth Magazine, 6, 7-8.

Misra, R., \& Castillo, L.G. (2004). Academic stress among college students: comparison of american and international students. International Journal of Stress Management, 11(2), $132-148$.

Oman, D., Shapiro, S.L., Thoresen, C.E., \& Plante, T.G. (2008). Meditation lowers stress and supports forgiveness among college students: a randomized controlled trial. Journal of American College Health, 56 (5), 569- 578.

Prihananto, P.E. (2012). Warga korea mahasiswa UI itu tewas jatuh dari lantai 18. Kompas. Diunduh dari http://nasional.kompas.com/.

Ridner, S.H. (2004). Psychological distress: concept analysis. Journal of Advance Nursing, 45(5), 536-545.

Ross, S.E., Niebling, B,C., Heckert, T.M. (2008). Sources of stress among college students. College Student Journal, 33(2), 312-317.

Santrock, J.W. (2008). Life span-development. (11th ed.). New York: McGraw-Hill. 